\title{
Correction to: Idiopathic neonatal hemoperitoneum presented as scrotal hematoma: it's a diagnostic challenge?
}

Alessia Salatto ${ }^{1}$, Flavia Indrio ${ }^{2 *}$, Vittoria Campanella ${ }^{1}$, Cosetta Maggipinto ${ }^{1}$, Raffaella Cocomazzi ${ }^{3}$, Francesco Canale ${ }^{3}$, Maria Nobili ${ }^{3}$, Gianfranco Maffei ${ }^{4}$ and Fabio Bartoli ${ }^{1}$

Correction: Ital J Pediatr 47, 207 (2021)

https://doi.org/10.1186/s13052-021-01161-x

The original article [1] mistakenly inverted each author's name; this has since been corrected.

\section{Author details}

${ }^{1}$ Department of Medical and Surgical Science University of Foggia, Pediatric Surgery Ospedali Riuniti Foggia, Foggia, Italy. ${ }^{2}$ Department of Medical and Surgical Science University of Foggia, Pediatric Surgery Ospedali Riuniti Foggia, Foggia, Italy. ${ }^{3}$ Department of Pediatric Surgery, AUO "Ospedali Riuniti", Foggia, Italy. ${ }^{4}$ Department of Neonatology, AUO "Ospedali Riuniti", Foggia, Italy.

Published online: 31 January 2022

\section{Reference}

1. Salatto A, et al. Idiopathic neonatal hemoperitoneum presented as scrotal hematoma: it's a diagnostic challenge? Ital J Pediatr. 2021;47:207. https:// doi.org/10.1186/s13052-021-01161-x. original author(s) and the source, provide a link to the Creative Commons licence, and indicate if changes were made. The images or other third party material in this article are included in the article's Creative Commons licence, unless indicated otherwise in a credit line to the material. If material is not included in the article's Creative Commons licence and your intended use is not permitted by statutory regulation or exceeds the permitted use, you will need to obtain permission directly from the copyright holder. To view a copy of this licence, visit http://creativecommons.org/licenses/by/4.0/. The Creative Commons Public Domain Dedication waiver (http://creativeco mmons.org/publicdomain/zero/1.0/) applies to the data made available in this article, unless otherwise stated in a credit line to the data. 